\title{
Planting of Jaboticaba Trees for Landscape Repair of Degraded Area
}

\author{
Marcia Regina Risso Gobato $^{1}$, Ricardo Gobato ${ }^{2}$, Alireza Heidari $^{3}$ \\ ${ }^{1}$ Seedling Growth Laboratory, Green Land Landscaping and Gardening, Bela Vista do Paraiso, Parana, Brazil \\ ${ }^{2}$ Laboratory of Biophysics and Molecular Modeling, State Secretariat for Education of Parana, Bela Vista do Paraiso, Parana, Brazil \\ ${ }^{3}$ BioSpectroscopy Core Research Laboratory, Faculty of Chemistry, California South University (CSU), California, USA
}

Email address:

mrrgobato@gardener.com(M. R. R. Gobato)

\section{To cite this article:}

Marcia Regina Risso Gobato, Ricardo Gobato, Alireza Heidari. Planting of Jaboticaba Trees for Landscape Repair of Degraded Area. Landscape Architecture and Regional Planning. Vol. 3, No. 1, 2018, pp. 1-9. doi: 10.11648/j.larp.20180301.11

Received: September 22, 2017; Accepted: November 11, 2017; Published: January 18, 2018

\begin{abstract}
The Jaboticaba, (Myrciaria cauliflora, Berg), known as black pearl fruit and grape of the trees in China. Native to South America, mainly in south-central Brazil, Paraguay and Argentina. Also grown in South Florida (U.S.), Caribbean, Venezuela, Peru and China (Mainland). The fruit stands out in the popular preference due to the sweetness of the fruits which makes the consumption in natura viable. Chosen as a suggestion of recovery and revitalization of the landscape of small urban area degraded by human intervention. From tasty fruits like tropical grapes, their flowers sprout on the trunk and on the main branches, and sometimes on the new branches. It presents small white flowers, of small pollen and yellow that emits a delicious fragrance. Once formed, the Jaboticaba will leave the central bed with lush environment presents good shading, delicious fruits to be enjoyed for human consumption and local wildlife, such as wild birds and hares.
\end{abstract}

Keywords: Eugenia cauliflora, Garden, Guapuru, Jaboticaba, Jia Bao Fuit, Landscape, Myrciaria cauliflora, Ybapuru

\section{Introduction}

The jaboticaba is a delicious fruit indigenous to Brazil, Bolivia, Paraguay and Argentina. The fruit is highly esteemed in Brazil. [1] Commonly found in parks, gardens and sidewalk of several streets both large and small cities. The fruit stands out in the popular preference due to the sweetness of the fruits which makes the consumption in natural viable. [2]

It was tried to describe the main species of jaboticaba found in South America. Its use in the landscape of cities as well as in gardens. It is used in cooking, home-made recipes for jams, jellies, sorbets and liqueurs. Its commercial production in Brazil, the United States of America and China.

It is suggested the planting of the jaboticaba tree, in a plot of land, in a residential plot, where it is degraded by human expansion and occupation, in the small town of Bela Vista do Paraíso, in the northern pioneer state of Paraná region South of Brazil. The land is abandoned, accumulating garbage, remains of construction material, debris, invasive plants, the original fauna and flora, and the same was occupied by pasture for cattle, before subdivision and urbanization.
The plant was chosen because it is a wild species, well appreciated by man, as well as local fauna, such as birds and small animals such as hare, rabbit, prey, etc.

Jaboticaba (Myrciaria cauliflora [Mart.] Berg) is a member of the Myrtaceae. Jaboticaba's are considered a complex of closely related species [3]. Relatives include guava (Psidium guajava L.), crape myrtle (Lagerstroemia indica, L.), and feijoa (Feijoa selloviana, Berg). The jaboticaba is native to the subtropical areas of Brazil and is planted commercially around Rio de Janeiro, Minas Gerais, Espirito Santo, São Paulo, Paraná and other provinces where there is an excellent large market for the fruit $[3,4,5,6]$.

Jaboticaba is grown in Brazil, Central and South America, and south Florida (U.S.), Caribbean, Venezuela, China.

In Brazil jaboticaba's grow from sea-level to elevations of more than 3,000 ft. Different plants vary markedly in how much frost they can take without severe damage, probably reflecting the species that a given plant belongs to. Some plants can take $24^{\circ} \mathrm{F}$ or lower and survive; others are damaged at $27^{\circ} \mathrm{F}$. In 1917 , a young tree at Brooksville, Florida survived a temperature drop to $18^{\circ} \mathrm{F}$. with only the foliage and branches killed back. In California jaboticaba's have been successfully grown in San Diego, Spring Valley, 
Bostonia, Encinitas, South Los Angeles and as far north as the San Jose and San Francisco Bay areas. The plant makes a suitable container specimen. $[6,7,8,9]$

In Florida, several factors favor its potential establishment in South Florida including the trees' adaptation to humid subtropical climate, the large Brazilian population that has settled in Florida, and few pest problems. The main drawbacks for commercial production include: the trees slow grow rate, taking 5 to 7 years to begin production; the lack of superior cultivars; difficulty in picking the fruit and; trees are not well adapted to the highly calcareous, high $\mathrm{pH}$ soils in southern Miami-Dade County, thus requiring minor element applications. [1]

Produced on a commercial scale in Guangdong, Shanghai, China (Mainland), [10] in production of seeds for export, in addition products industrialized foods such as jams, bar cereals, sweets and production of seedlings for planting. [11] In the pharmaceutical industry, they are used in cream with antiaging properties. [2]

Mature trees have tolerated $26-29^{\circ} \mathrm{F}$ for a few hours in Florida and there is a report of a young tree with only leaf and branch damage at $18^{\circ} \mathrm{F}$. [6] Jaboticaba's flower more profusely under cold and dry conditions during the winter. [3, 12] They require full sun, respond well to rainfall or irrigation, and are very susceptible to toppling.

Jaboticaba's grow best in rich, deep, slightly acid soils. Trees can also be grown in rocky alkaline or sandy soils if supplied with minor nutrients. The tree does not tolerate saline water or drought, but responds well to mulching, composts, and peatmoss soil amendments. [13] Trees can be grown in artificial media in containers, e.g., 20 gallon or greater containers. The tree can also be used as an ornamental specimen or for hedges. [14, 15]

\subsection{Common Names}

Brazilian Grapetree, Jaboticaba (English); Jabuticaba, Jabuticaba-açu, Jabuticaba-de-sabará, Jabuticaba-murta, Jabuticaba-paulista, Jabuticabeira (Portuguese of Brazil); Stamjaboticaba (Swedish); [16, 17] Guaperu, Guapuru, Hivapuru, Sabara, Ybapuru, (Indigenous names in Brazil) Cabelluda $[6,7,8,9]$, grapes of trees, tree pearl fruit black, Garbo fruit [10] (in Chinese).

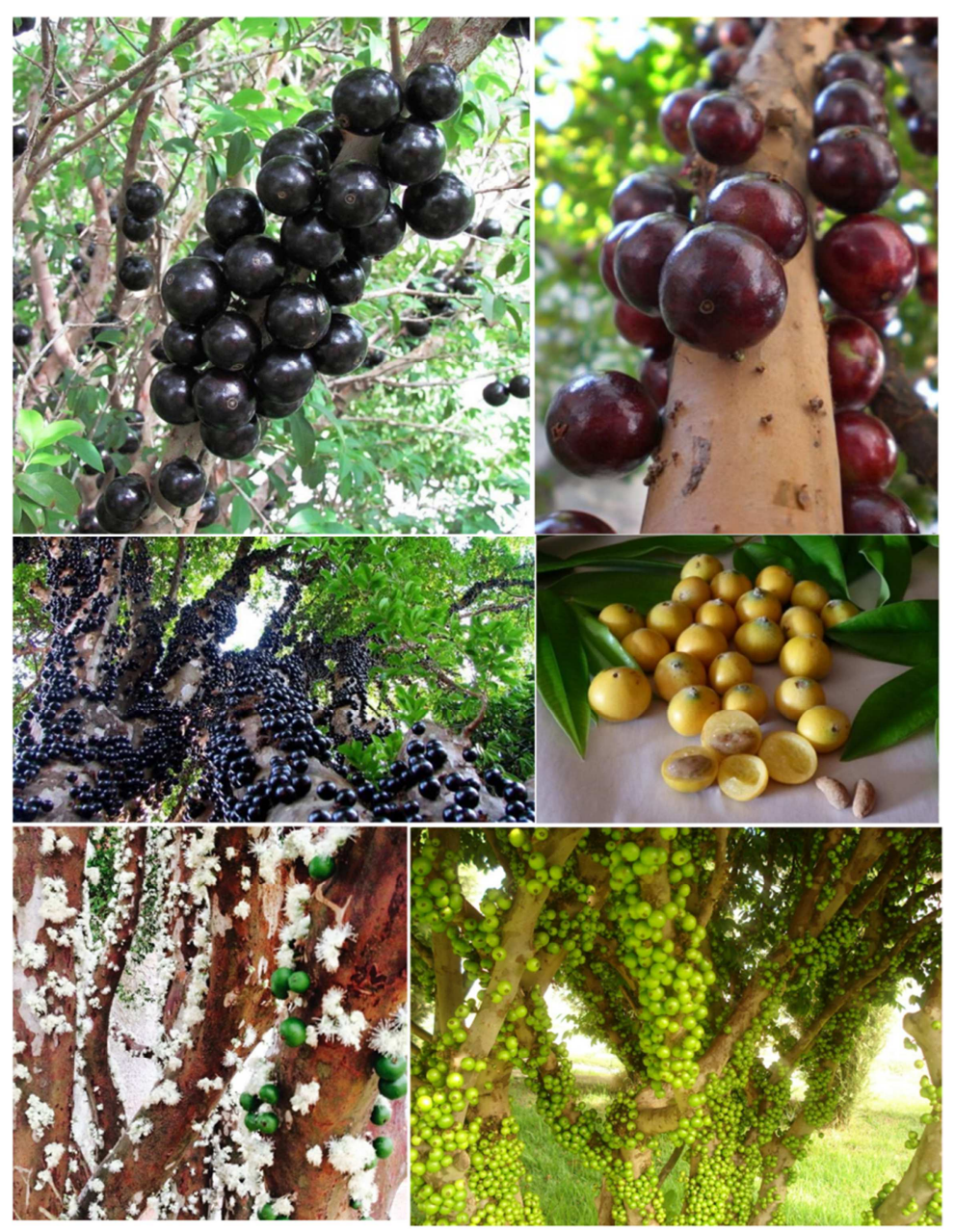

Figure 1. Up Left, fruits in the trees of Jaboticaba Hybrid (Myrciaria cauliflora). [25] Up right fruits in the trees of Jaboticaba Red Hybrid (Plinia cauliflora $x$ aureana). [26] In the middle and the left, fruits of Jaboticaba Yellow (Myrciara glazioviana). [26] In the middle and the right, fruits in the trees of Jaboticaba Hybrid (Myrciaria cauliflora). [27] Down left, flowers in the stem of the trees White Jaboticaba (Myrciaria aureana) and down right fruits in the trees of White Jaboticaba (Myrciaria aureana). [25] 


\subsection{Botanical Description}

Trees are small to medium sized, evergreen with symmetrical, dense canopy either single or sometimes multitrunked. [18] Trees grow slowly and in Florida seldom exceed 15 feet and may be used as specimen trees in backyards because of their ornamental value. The attractive scaly bark of the trunk and branches has whitish to dark brown patches and some trunks have a reddish color. The lanceolate to elliptic, opposite leaves are 1-2 inches long and half an inch wide, dark green, smooth and shiny.

Flowers are white, small in size, and profuse in adult trees, single or in clusters arising directly from the trunk and fairly thick branches ( $>1 / 2$ inch). Trees bloom several times a year. Fruit (berries) are muscadine grape-like, globose to round and have a maroon to black skin. The skin is $33-49 \%$ of the fruit weight. [19] Fruits weigh 3-15 gm (0.1-0.8 oz) and are $>1 / 2$ to $3 / 2$ inches in diameter. The pulp is whitish, gelatinous with $1-4$, oval to round and laterally compressed seeds. Seeds are $13-35 \%$ of fruit weight. Fruits are produced directly from the trunk and branches, singly or in clusters with several crops a year. The trees usually take 7 to 10 years to fruit from seed. Fruits are excellent to pleasant to eat and have a subacid and sweet flavor with 14.0 Brix. [20]

Jaboticaba usually have a main crop in the spring and 3 to 5 other smaller crops during the year. [20, 21, 22] It takes 2030 days from bloom to fruit maturity. In Florida, yield is estimated at 30-125 lbs per adult tree but mostly 30 to $50 \mathrm{lbs}$. Production may begin 5 to 8 years from seed and about 6-7 years from vegetatively propagated by grafting, cuttings, air layering [1, 21, 22, 23, 24].

\subsection{Scientific Classification}

\section{Kingdom: Plantae \\ Division: Magnoliophyta, Angiosperms \\ Class: Magnoliopsida, Eudicots \\ Subclass: Rosidae \\ Order: Myrtales \\ Family: Myrtaceae \\ Genre: Plinia}

Species: $P$. cauliflora

Binomial name: Plinia cauliflora (Mart.) Kausel [17, 29]

Synonyms: Eugenia cauliflora (Mart.) DC, Eugenia jaboticaba Kiaersk, Myrcia jaboticaba Baill, Myrciaria cauliflora (Mart.) O. Berg, Myrciaria jaboticaba (Vell.) O. Berg, Myrtus cauliflora Mart. (basionimo), Myrtus jaboticaba Vell. [16]

\subsection{Main Species}

Myrciaria coronata Mattos. Small tree, measuring approximately $3 \mathrm{~m}$ in height, has flattened terminal branches, leaves with short petioles, globular fruits approximately 2.7 $\mathrm{cm}$ in diameter. Commonly known as crowned jaboticaba, or crown jaboticaba, occurs mainly in São Paulo. [18]

Myrciaria oblongata Mattos. Tree about $5 \mathrm{~m}$ high; Subachatated terminal branches, short petiole leaves, reddish, very glandular; Ovate-elliptic fruits to self - purple ellipticals 2 to $3.2 \mathrm{~cm}$ in length by 2 to $2.7 \mathrm{~cm}$ in diameter 1 to 4 seeds. Known as jaboticaba azeda, it occurs mainly in São Paulo.

Myrciaria spirito-santensis Mattos. Size of approximately $4 \mathrm{~m}$ tall, brown branches, with terminal twigs and new hair; Opposite or subopposite leaves of short petioles. It occurs mainly in the Holy Spirit.

Myrciaria grandifolia Mattos. Tree of approximately $5 \mathrm{~m}$ in height, cylindrical branches, with end subachatada, gray and ser'iceos terminal branches. Leaves with petioles of 5 to $6 \mathrm{~mm}$ in length; Fruits with $2.2 \mathrm{~cm}$ in diameter, globose, smooth, atropurpurea. Known as jaboticaba great, or "jaboticatuba", occurs mainly in Minas Gerais.

Myrciaria peruviana (Poir) var. trunciflora (Berg) Mattos. Trees with about $8 \mathrm{~m}$ in height; Cylindrical branches, and flattened new twigs; Dark leaves with petioles approximately $3 \mathrm{~mm}$ in length; Globular berries, about $2 \mathrm{~cm}$ in diameter, black; 1 to 4 seeds. Known as "jabuticaba de cabinho", it occurs in the states of MG and ES, in Brazil, and also in Paraguay and Argentina.

Myrciaria aureana Mattos. Tree about $3 \mathrm{~m}$ high; Yellowish bark; Cylindrical branches, with bark detachment being the terminal branches and new yellowish gray possessing seriaceous pilosity; Opposite leaves, with petioles $3 \mathrm{~mm}$ long, cacti, have dark, numerous and little visible glands; Subglobose-oblique fruits, 15 to $18 \mathrm{~mm}$ in length by 19 to 21 $\mathrm{mm}$ in diameter, light green; 1 to 4 smooth, light yellow seeds. Known as white, it occurs in São Paulo. [18]

Myrciaria phitrantha (Kiaersk) Mattos. Approximately $7 \mathrm{~m}$ high; Cylindrical branches; Leaves with petioles of 5 to 10 $\mathrm{mm}$ in length, have semi-translucent scores; Berries about 2.4 $\mathrm{cm}$ in diameter, sub-globous. Known as cost. It occurs in São Paulo. [18]

Myrciaria jaboticaba (Vell) Berg. Tree from 6 to $9 \mathrm{~m}$ in height; Thin and cylindrical branches, the terminal branches being new, flattened; Leaves with a petiole of 1.5 to $2 \mathrm{~mm}$ in length, ciliated when new; Fruits of 1.6 to $2.2 \mathrm{~cm}$ in diameter, subglobous or globose, black and smooth; 1 to 4 seeds. Known as it will know, it occurs in Brazil, Paraguay and Argentina. [18]

Myrciaria cauliflora (DC) Berg. Has flat and flat terminal branches; Leaves with petioles $3 \mathrm{~mm}$ long, membranous; Globose fruits, black, 2.2 to $2.8 \mathrm{~cm}$ long by 2.2 to $2.9 \mathrm{~cm}$ in diameter; 1 to 4 seeds. Known as "paulista assu" (or açu), and ponhema. It occurs in Brazil, in general. [18]

\subsubsection{Myrciaria cauliflora var Sabara}

Botanical Name: Myrciaria cauliflora var. Sabara [28]

Myrciaria cauliflora. Has a habit of producing the fruit directly on the trunk makes this a striking tree. Fruit is similar to a grape with a sweet and aromatic flavour. New growth is a coppery colour and beautiful honey scented flowers makes it a very ornamental tree. Bears heavy crops of quality fruit that can be eaten fresh from the tree. Often fruiting up to 3 times per year. Time from flowering to fruit being ready to eat is only 30 days. [26] 
The jaboticaba's habit of producing the fruit directly on the trunk makes this a striking tree. Fruit is similar to a grape with a sweet and aromatic flavour. The new growth is a coppery colour along with their beautiful honey scented flowers makes it a very ornamental tree. Bears heavy crops of quality fruit that can be eaten fresh from the tree. Often fruiting up to 3 times per year. Time from flowering to fruit being ready to eat is only 30 days. [26]

\subsubsection{Myrciaria sp. Grimal}

Botanical Name: Myrciaria sp. Grimal

Ornamental evergreen tree from Brazil grown for unusual sweet black fruit which cover the inside trunks. Crops several times per year. Flowering to fruit maturity only takes about 1 month. Larger fruit than small leaf selection, but skin a little tougher.

Other Names: Jia Bao fruit, Garbo fruit (嘉宝果, in Chinese) [30, 31, 32], Brazilian Grape, Jabotica, Jabuticabeira, Guaperu, Guapuru, Hivapuru and Ybapuru. [26]

\subsubsection{Myrciara glazioviana}

\section{Botanical Name: Myrciara glazioviana}

Yellow fruiting species with a distinctive sweet tangy flavour reminiscent of pineapple. We consider this tree a showpiece. Its lime green leaves have an unusual soft, almost powdery appearance and its beautiful golden green pendulous branches make it a worthy feature in the garden for its highly ornamental nature. The fruit of the black jaboticaba is becoming more popular and widespread (I even found some on the shelf of a local grocery store here in Lismore last week) while the yellow jaboticaba still remains a mystery to many. A prerequisite for enjoying the fruits of the Black Jaboticaba is patience. They can often take 6-7 years to come to fruit. [26]

However, we have found the Yellow Jabot produce fruit in as little as 3 years. It is a small bushy tree, usually growing to 3-4 $\mathrm{m}$ in the subtropics of Australia, however I have seen photographs of the tree, in Brazil (its place of origin), with a couple of young boys perched high in the branches. These trees must have reached $9-10 \mathrm{~m}$ tall. The tree has a moderate cold tolerance but is best protected from frost. It is a suitable container grown tree in those areas that do receive frost and can be moved to a sheltered position during the cooler months. They are happy in full sun or part shade and are generally small enough to find a place in most gardens. [26]

They are relatively wind tolerant but will not enjoy salt spray. They particularly enjoy deep rich soil pH 5.5 to 6.5 but with regular nutrient application can be grown in most soil types. While the fruits have some similarities to the Black Jaboticaba, they are quite different in appearance, having a slightly furry yellow skin instead of the smooth shiny black skin. The fruit contains a gelatinous whitish pulp which has a pleasant, slightly acid flavor. A single tree will produce fruit, but cross pollination has shown to increase productivity. When planting a jaboticaba, the crown (uppermost) roots should be 2 to 3 inches higher than the surrounding soil levels to provide water runoff. Peat, compost or rotted manure may be mixed with the soil from the planting hole to improve it. The soil should be a well-aerated mixture. [26]

\subsubsection{Plinia cauliflora $x$ Aureana}

Botanical Name: Plinia cauliflora $\mathrm{x}$ aureana

Red jaboticaba is a seedling hybrid, also called Precocious Jaboticaba. This makes for a very fast fruiting plant. Can fruit in 3-4 years, as opposed to 6-8 years for regular jaboticaba. Great tasting and dwarfing habit. [26]

\subsubsection{Myrciara coronate}

\section{Botanical Name: Myrciara coronata}

The largest fruits of all our jaboticaba's, this variety can produce golf ball sized fruits and is aptly named the Giant Jaboticaba. Looking at the picture you can see the normal sized Jaboticaba fruit on the left vs The Giant Jaboticaba fruit on the right. It is an Ornamental evergreen tree from Brazil grown for unusual sweet black fruit which cover the inside trunks. Note this is the very first release and only 25 will be available for sale in 2015 hence why it is in our rare and collectable category. We are hoping to produce more at a later date unknown. [26]

\subsection{Utilization, Nutritional Aspects, Socio-climatic Requirements and Pest Control}

\section{Utilization}

The wood is resistant and can be used for the preparation of beams, supports, sleepers and other internal works.

Fruit: can be consumed naturally or used in the preparation of sweets, jellies, liqueurs, wine, vinegar, etc. [33] In industry, the fruit is used for the preparation of brandy, jellies, jeropiga (artificial wine), liqueur, juice, and syrup, and the fruit extract is used as a coloring agent for wines and vinegars. [34]

In homemade medicine the bark tea is used to treat angina, and erysipela. The fruit wedge, in tea, is intended for the treatment of asthma. Jaboticaba is also used for gargling, as jaboticaba broth is effective against acute and chronic inflammations of the mouth. The jaboticaba tree also has the following phytotherapic indications: antiasthmatics, inflammation of the tonsils, inflammation of the intestines, hemoptysis, erysipelas, and chronic esquinencia. [30, 31, 32, 34]

The topic cosmetics applications with antioxidants actives reduce the oxidative damages induced by UV (ultraviolet) radiation, and are a good alternative for the skin protection against "photo aging". Jaboticaba's peels have higher concentrations of phenolic compounds, of antioxidant activities and anthocyanin content, when compared to other fraction. [35]

Study's was to determine the effect of hydroalcoholic extract of $M$. cauliflora (HEMC) on vascular tension and blood pressure in rats. Study in vivo show that the intravenous infusion of HEMC produced hypotension and increased aortic blood flow with no changes in heart rate. Tese fndings showed that HEMC induces endotheliumdependent vascular relaxation and hypotension with no alteration in heart rate. [36] 
Jabuticaba has high acceptance and nutritional importance such as mineral content, vitamins and phenolic compounds, which are antioxidant substances. Studies of dairy products grown with addition of jabuticaba and green banana biomass are well accepted by consumers in all attributes of the palate and present potential for use by the food industry. [37]

The production of jabuticaba (Myrciaria jaboticaba) vinegar with cell immobilization, whose comprises the retention of metabolically active cells within a polymeric matrix. Compounds (aldehydes, higher alcohols, terpene, acetate, diether, furans, acids, ketones and ethyl esters) were found in the jabuticaba vinegar. [33]

\section{Nutrition aspects}

They are good sources of vitamins B2 and B3, protein and calcium. They are used against asthma. Each $100 \mathrm{~g}$ of the fruit has $44.9 \mathrm{cal} ; 11.2 \mathrm{~g}$ of glycines; $0.54 \mathrm{~g}$ protein; $9 \mathrm{mg}$ of calcium; $60 \mathrm{mg}$ of phosphorus; $1.26 \mathrm{mg}$ of iron; $8.3 \mathrm{mg}$ of sodium and $13 \mathrm{~g}$ of potassium. They also have, for every 100 $\mathrm{g}, 60 \mathrm{mg}$ of vitamin B1; $160 \mathrm{mg}$ of vitamin B2, $12.80 \mathrm{mg}$ of vitamin C, $2 \mathrm{mg}$ of Niacin. [1, 24]

The germplams of jaboticaba are rich. Its fruits contain rich amount of anthocyanin and phenolic compound which have some functions, including high anti-oxidation, and prevention of chronic diseases, such as, diabetes and hyperlipidemia. [38]

\section{Socio-climatic requirements}

The jaboticaba tree is considered a plant of subtropical origin, but with good adaptation to the tropical climate [18, 39], supporting well up to $-3^{\circ} \mathrm{C}$, but supporting a short period of water shortage, and requires good soil moisture [18]. It needs low temperatures to flourish [40].

In relation to altitude, it occurs in Brazil, from sea level up to 1,400 meters altitude $[18,24]$. It is classified as mesophytic or heliophite and selective hygrophyll. [18]

In relation to the soil, it has developed well in several soil types, preferably silica-clayey, or clay-siliceous, deep, fertile and well drained. [41]

Pest Control

Pest control in jaboticaba can be done with the insecticide Deltamethrin. [42]

\section{Production in Brazil}

Record jaboticaba harvest yields profit and employment in Casa Branca, SP. Municipality accounts for $60 \%$ of fruit production in the State of São Paulo. Catchers receive up to $\mathrm{R} \$ 2,000.00$ every 15 days of harvest. Responsible for $60 \%$ of state production of jaboticaba, Casa Branca (SP) registers in 2013 a record harvest of the fruit, generating profit for the farmers and more vacancies of employment in the field. [43]

The Institute of Agricultural Economics estimates that the jaboticaba harvest this year produces 2,700 tons in the state, 1,700 tons in Casa Branca alone, a city that has 22 thousand feet of jaboticaba and is the largest producer in Sao Paulo. According to the agronomist J. C. Nogueira the climate contributes to the good numbers. "The rains in the right period, at the right time, the heat. For all this sequence of factors, coupled with the cultural dealings that have been in place for many years, the trend of this harvest is breaking the record," he said. [43]

F. E. F. Fagan is a traditional producer of jaboticaba and on his 35 hectare farm, there are 3,300 feet of fruit. This year it has already harvested 130 tonnes and will close the harvest with a production $10 \%$ higher than last year. "The part of the rains helped a lot because there is an economy with irrigation and whenever it comes from above is better for the fruit," he commented. [43]

In the neighboring farm, J. R. Fagan has 20 hectares of land with feet of jaboticaba and the 130 tons harvested until the month of October surpasses all last year's harvest of one hundred tons. "There has been a lot of harvest, a lot of volume, but it's being profitable in quantity and the price is reasonable, the price is good," he said. [43]

Besides profit, the good harvest also generates jobs. In a same farm, 20 people were hired to reinforce the harvest in the orchards, and as the production is at the height of the cycle of jaboticaba has catcher who manages to earn up to R\$ 2 thousand per fortnight. "It gave a lot of fruit and is giving to make good money for us, giving to earn a lot more and we will see even more until the end of the year we will be picking up a lot more", said J. F. Machado, catcher who earns R\$ 130.00 per day With the harvest. [43]

In the shack, where fruits are sorted and packaged for distribution, more jobs were generated. "During the year there is no job and here, when it has the crop, it gives us a lot of work," said assistant J. Rangel. "We can get some money to help the family," said M. de S. Coelho. [43]

Fruit consumers also celebrate. The cook W. de A. M. makes sweets and salted out. With creativity, the table wins dishes like the snack of shank with spicy jaboticaba sauce, jellies, mousses and juices. It has saved, because the raw material is more in account. "The value is $\mathrm{R} \$ 5.00$ a pound and it's great for us to increase production more", he said. [43]

Feet of jaboticaba loaded generate income and saw attraction in Goiás Plant of Brazilian origin only becomes productive after 15 years. In all, 150 farms produce jaboticaba in Hidrolândia. The feet of jaboticaba, in Goiás, are loaded. For two months, the fruit becomes a tourist attraction and generates income for many farmers. [44]

Altogether, 150 farms produce jaboticaba in Hidrolândia, a region responsible for $60 \%$ of fruit production in Goiás. The farmer P. A. Sousa has 42 thousand feet of honey, which is a sweeter variety and has adapted very well to the Brazilian Cerrado. The plant of Brazilian origin only becomes productive after 15 years of planting, but here it bears fruit for 50 years and is usually grown in consortium with other fruits. [44]

Goiás is the third largest producer of jaboticaba in the country. The season runs from the beginning of September until the end of October and the control of the production of the fruit is made with the irrigation by flood that begins in the month of July in different places of the orchard. With this, in the month of September have feet loaded with ripe, green or still flowering fruits. The service is made by V. Bugres, who knows with precision when the jaboticaba's of each foot will 
be ready for the consumption. [44]

The 180,000 tons of fruit are sold in large cities or transformed into various products such as wine, brandy, cosmetics, sweets and even handicrafts, but the tradition of sucking jaboticaba on the foot remains the most important source of income for producers and a Satisfaction to the thousands of tourists who appear on the site. "It's very beautiful, the feet are pretty full, the place is nice, you have to enjoy a lot, right?" Says L. Senna, Realtor. [44]

Table 1. Nutritional information on the fruits of jabuticaba (mg/g) (Myrciaria cauliflora).

\begin{tabular}{llllll}
\hline Protein & Sugar & Fat & Water & Fiber & Ash \\
\hline 1.70 & 126.40 & 0.40 & 867.60 & 0.70 & 3.20 \\
Carotene & Retinol & VB1 & VB2 & VB3 & VC \\
0.0006 & 0.0001 & 0.0002 & 0.0019 & 0.0024 & 0.2167 \\
Potassium & Sodium & Calcium & Magnesium & Iron & VE \\
1.51 & 0.018 & 0.063 & 0.09 & 0.0049 & 0.0073 \\
Manganese & Zinc & Copper & Phosphorus & Selenium & - \\
0.0012 & 0.0033 & 0.0027 & 0.092 & 0.000007 & - \\
\hline
\end{tabular}

VB1: Vitamina B1; VB2: Vitamina B2; VB3: Vitamina B3; VC: Vitamina C; VE: Vitamina E. [45]

\section{Use of Jaboticaba in Cookery}

Various products can be obtained from the jaboticaba. The following are some recipes.

\subsection{Jaboticaba Cake}

Ingredients:

100 grams water biscuits;

1 tablespoon melted margarine;

1 teaspoon ground cinnamon;

1 tablespoon powdered sweetener;

3 cups jaboticaba;

2 cups water;

$1 / 2$ cup powdered sweetener;

1 teaspoon cornstarch;

$1 / 2$ unflavored gelatin powder envelopes;

3 egg whites;

$1 / 2$ cup light cream.

How to Prepare:

Beat the cookies on the processor until it forms a farofa. Put in a pan with the margarine until starting to brown. Remove and add the sweetener and cinnamon. Put the bottom of a way to open. Bring the jaboticaba with the water to the fire and leave to cook until the shell breaks. Let it stay warm and hit the blender. To pass through a colander and to toast to the fire with the sweetener, the starch. Leave to thicken. Dissolve the gelatin in 4 tablespoons of water and in a water bath. Reserve 1 cup jaboticaba jelly. Mix remaining, gelatin, beaten snow white and cream. Put on the pie dough and bring to the refrigerator. When firing, remove from the rim and serve with the syrup. [46]

\subsection{Jabuticaba Jelly}

Ingredients:
3 liters of jaboticaba;

About five American cups of crystal sugar, according to the amount of fruit juice.

Way of preparing

Wash the jaboticaba. Squeeze in a pan and bring to the fire with the peel and the lump. Once boiling, stir and remove from heat. Allow to cool, pass in the sieve of taquara, easily found in municipal markets. Strain the liquid back into the colander. Measure six cups of juice and five American cups of sugar. Take to the fire and let the point. Important tip: let drip the jelly in a glass with water. When the ball hits the bottom of the glass and dissolves, it is already on point. Then just put it in a sterilized glass.

Cover only after the jam is cold. [46, 47]
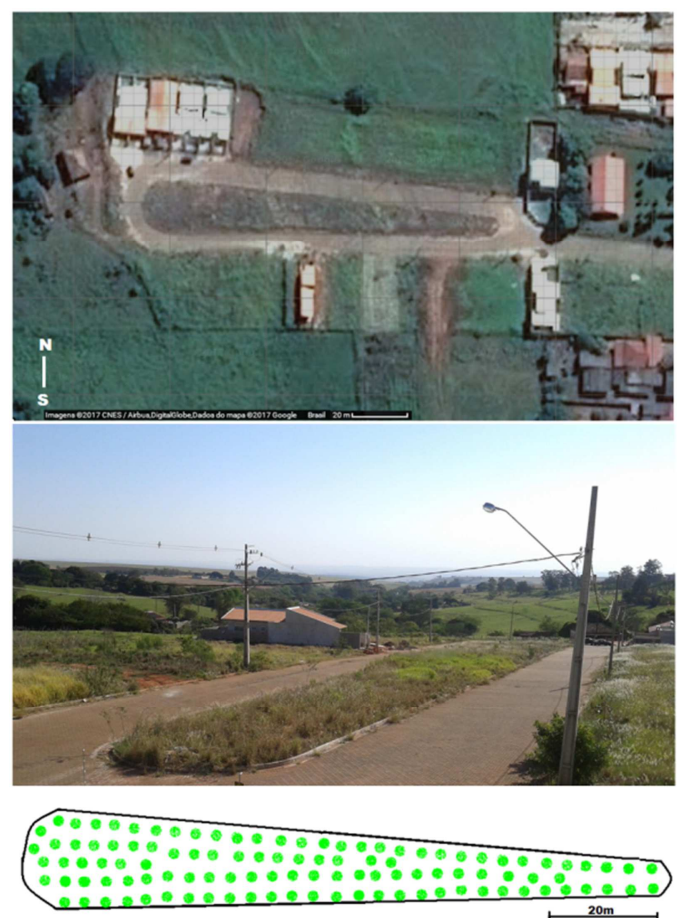

Figure 2. Above, there is a satellite image, of coordinates $22^{\circ} 59^{\prime} 50.1^{\prime \prime} \mathrm{S}$ $51^{\circ} 11^{\prime} 50.0^{\prime \prime} \mathrm{W}$, of the residential complex, with the center of the central plantation of the trees of jaboticaba. [48] In the center, an image of the central plot, from the residential, with a view from west to east, towards the flowerbed. One can visualize the area of central plot totally degrading, with rubbish, rubble and invading plants. Below is the approximate representation of the planting arrangement of the jaboticaba's trees.

\subsection{Jaboticaba Ice Cream}

Ingredients:

1 liters of jaboticaba juice;

1 cup and a half of crystal sugar;

1 cup powdered milk;

1 tablespoon neutral alloy;

1 tablespoon of hydrogenated fat.

Way of preparing

Wash the jaboticaba's thoroughly. Then squeeze the fruit in a pan, leaving the peel and the core. Take to the fire. Once boiling, pass on the sieve of "taquara", easily found in municipal markets. You can also use the plastic sieve. The 
aluminum is no good. Strain on a cloth strainer and then the juice will be ready. Then put all the ingredients in the blender, minus the hydrogenated fat. Crash for approximately 20 minutes. Leave in the freezer overnight. The next day divide the dough into two parts, because the homemade mixer does not hold everything at once. Beat each part with half a spoonful of hydrogenated fat. The dough will grow and the ice cream will be ready. Put in pots and refrigerate. [46, 47]

\subsection{Liquor}

Ingredients:

$400 \mathrm{~g}$ of jaboticaba;

$200 \mathrm{~g}$ of sugar;

$200 \mathrm{~cm}^{3}$ of water;

$200 \mathrm{~cm}^{3}$ alcohol 95 G.L.

Way of preparing:

Crush the jaboticaba's, enjoying all the fruit. Infuse into the alcohol for 24 hours. Coar in flannel. Make a syrup of water with sugar and mix it to the infusion. Bottling and letting age for 6 months, then filter. [18, 46]

\section{Methods of Tree Planting}

The chosen area Figure 2, is approximately $1700 \mathrm{~m}^{2}$, calculates through the satellite image [49], with an altitude bet ween 590 to 601 meters above sea level. Located in the municipality of Bela Vista do Paraíso, Paraná, Brazil. Subtropical climate region, UTC-3 time zone, latitude and longitude, $22^{\circ} 59^{\prime} 50.3^{\prime \prime} \mathrm{S}$ and $51^{\circ} 11^{\prime} 49.7^{\prime \prime} \mathrm{W}$, respectively. [48]

The arrangement of the jaboticaba trees is described in Figure 3, with spacing between the plants between 3 and 5 meters, being necessary 110 plants approximately, with average of seven years of age. This is necessary due to the slow growth of the jaboticaba, until a good formation of canopy, allowing good shading, of all the central bed, that is, the closing of the canopies. After that, using shading for the parking lot, with the edges of the central bed, they provided shade to vehicles, and the reduction of floor temperature of the public road and the central bed. As complementary cover of the soil, until the formation of crown of the trees, one can do the planting of grasses.

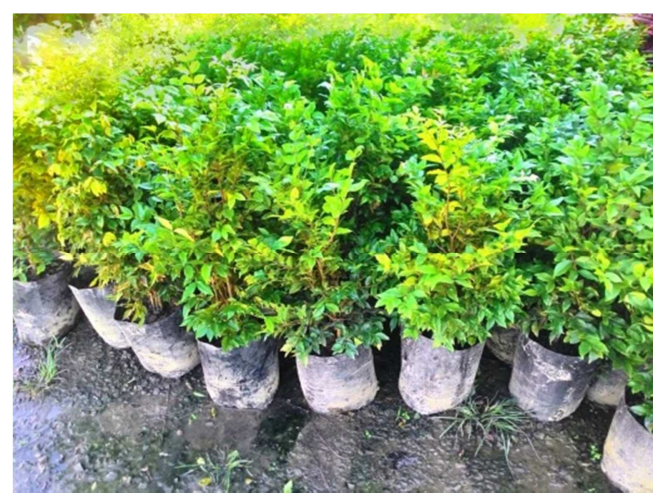

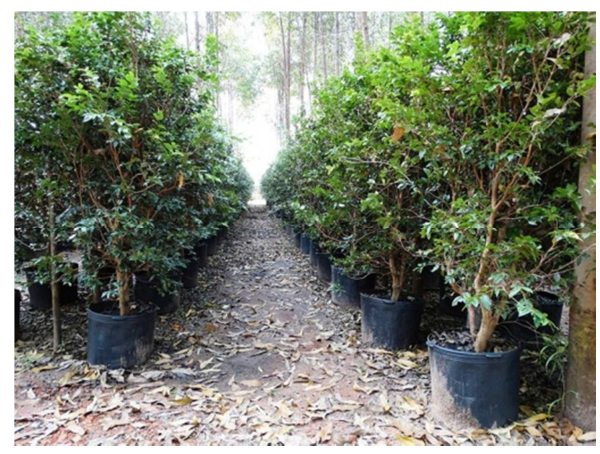

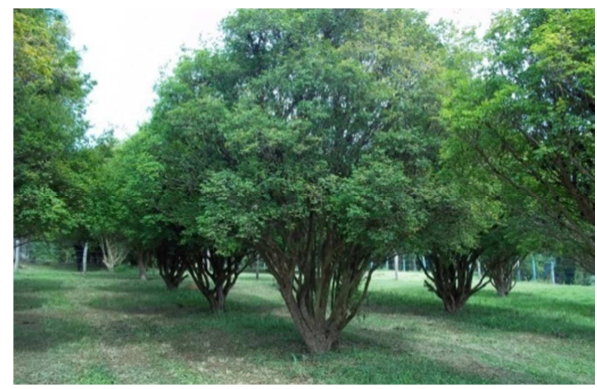

Figure 3. Up seedlings ready for planting White Jaboticaba (Myrciaria aureana) approximately one meter high, ready for planting. In the centerJaboticaba Hybrid (Myrciaria cauliflora) trees with approximately two meters, ready for planting. Down the image of orchard of jaboticaba trees, White Jaboticaba (Myrciaria aureana). [25]

Before planting it is necessary: removal debris, stones, garbage, invasive plants, among other objects foreign to the environment that are in the place.

The seedlings with an average of eight years of growth in the Brazilian market cost approximately R\$ 1,000.00/plant, approximately U\$ 319.00, in the quotation of the Brazilian currency against the U\$ = dollar. One dollar on September 19, 2017, U\$ $1.00=\mathrm{R} \$ 3,136$ [50]. The grasses have an approximate cost of $\mathrm{R} \$ 10.00 / \mathrm{m}^{2}$, already placed, or even the sowing of fast-growing flowers at a lower cost.

\section{Discussions}

In Figure 1 the images are visualized:

Up Left, fruits in the trees of Jaboticaba Hybrid (Myrciaria cauliflora); [25]

Up right fruits in the trees of Jaboticaba Red Hybrid (Plinia cauliflora $\mathrm{x}$ aureana); [26]

In the middle and the left, fruits of Jaboticaba Yellow (Myrciara glazioviana); [26]

In the middle and the right, fruits in the trees of Jaboticaba Hybrid (Myrciaria cauliflora); [27]

Down left, flowers in the stem of the trees White Jaboticaba (Myrciaria aureana); and down right fruits in the trees of White Jaboticaba (Myrciaria aureana). [25]

In Figure 2 the images are visualized:

Above and to the left, there is a satellite image of the residential complex, with the center of the central plantation of the trees of jaboticaba, of coordinates $22^{\circ} 59^{\prime} 50.1^{\prime \prime} \mathrm{S} 51^{\circ}$ 11 ' 50.0' W.

Above and to the right, an image of the central plot, from 
the residential, with a view from west to east, towards the flowerbed.

One can visualize the area of central plot totally degrading, with rubbish, rubble and invading plants.

Below is the approximate representation of the planting arrangement of the jaboticaba's trees.

In Figure 3 the images are visualized:

Up Left seedlings ready for planting White Jaboticaba (Myrciaria aureana) approximately one meter high, ready for planting; Up right, Above and to the right, Jaboticaba Hybrid (Myrciaria cauliflora) trees with approximately two meters, ready for planting;

Down the image of orchard of jaboticaba trees, from which it is expected that the central planted can be planted, but that will be more densely packed with trees, White Jaboticaba (Myrciaria aureana).

\section{Conclusions}

After the planting and adaptation period of the plants, local inhabitants, as well as the fauna, can enjoy the orchard formed. There will be a significant improvement in the quality of life of the local residents, due to the beauty, the reduction of temperature, increase of the relative humidity of the place, shading, harvest of the fruit in the own tree in natural. It will attract a significant amount of birds, and other wild animals that will benefit from food and shelter.

\section{References}

[1] C. F. Balerdi; R. Rafie and J. Crane. Jaboticaba (Myrciaria Cauliflora, Berg). A Delicious Fruit with. An Excellent Market Potential. Proc. Fla. State Hort. Soc., (119):66-68, 2006.

[2] E. Borges; L. G. C. Monte; R. dos S. Rocha; O. Modesto Jr. and T. F. Modesto. Vinho de Jaboticaba. In III Encontro Científico e Simpósio de Educação UNISALESIANO. Educação e Pesquisa: a produção do conhecimento e a formação de pesquisadores, Oct. 17-21, 2011.

[3] W. J. Wiltbank; N. N. J. Chalfun and O. Andersen. The Jaboticaba in Brazil. Proc. Amer. Soc. Hort. Sci., 27:57-69, 1993. Proceedings of the Florida State Horticultural Society, Florida, US.

[4] G. Coppens and D. Libreros. Myrciaria cauliflora (C. Martius) O. Berg (Myrtaceae). http://www.ciat.cgiar.orglipgri/fruits from america's/frutales, 21 May 20062001

[5] P. Gomes. Fruticultura Brasileira. Livraria Nobel S. A., pp. 446 ed., 1972.

[6] J. F. Morton. Fruits of Warm Climates. J. Morton Publisher, Miami, FL, 505 pp edition, 1987.

[7] L. S. Maxwell and B. M. Maxwell. Florida Fruit. Number p. 69. Lewis S. Maxwell Publisher, 1984.

[8] W. Popenoe. Manual of Tropical and Subtropical Fruits. Hafner Press, facsimile of the 1920 ed. 1974. pp. 299-302.
[9] Jaboticaba. California Rare Fruit Growers Inc., Aug. 312017.

[10] The first stock meeting in. Sea Jiabao Co., Ltd. January 23, 2017.

[11] Shangai Fairy Valley Industrial Co. Ltd. Alibaba.com, Sep. 20 2017. https://fairyvalley.en.alibaba.com/.

[12] D. Giacometti and E. Lleras. Subtropical Myrtaceae: Jaboticaba (Myrciaria spp.). http://www.fao.org/docrep/t0646e/T0646EOm.htm, May 21, 2006.

[13] R. L. Phillips and S. Goldweber. The Jaboticaba. Hort. Sc. Dept., 1978. Document FC-39, 2 pp.

[14] E. D. Ackerman. Jaboticaba nutrition experiment. J. Proc. Fla. State Hort. Soc., (91):187-189, 1978.

[15] W. F. Whitman. Five Decades with Tropical Fruit: A Personal Journey. 476 pp. edition, 2001.

[16] CC BY-NC-SA 3.0. Creative commons. Wikipedia, The Free Encyclopedia, May 2016.

[17] Taxon: Plinia cauliflora (Mart.) Kausel. U. S. National Plant Germplasm System, 24 Mar. 2017. https://npgsweb.arsgrin.gov/gringlobal/taxonomydetail.aspx?id=465344. Aug. 30, 2017.

[18] L. C. Donadio. Jabuticaba (Myrciaria jaboticaba (Vell.) Berg). Frutas Nativas, 3. Funep, Jaboticabal, São Paulo, 2000.

[19] N. de Jesus; A. B. Martins; E. J. de Almeida; J. B. Vieira; R. Devos; E. J. Scaloppi; R. Aparecida and R. F. Cunha. Caracterização de quatro grupos de jaboticabeiras nas condições de Jaboticabal. Revista Brasileira de Fruticultura, $26(3): 1-8,2004$.

[20] A. Mootoo and G. Henry. Introducing the jaboticaba, a relatively newcomer to the Caribbean. Postharvest and Fruit Agronomy Units, Research Division, Ministry of Agriculture, Land and Marine Resources, Trinidad, 2 pp., 1996.

[21] O. Duarte and M. Huete. Propagation of jaboticaba by terminal leafy cuttings. Proc. Interamer. Soc. Trop. Hort., (40):57-60, 1996a.

[22] O. Duarte and M. Huete. Propagation of jaboticaba by air layers, hardwood cuttings and graftag. Proc. Interamer. Soc. Trop. Hort., (40):61-64, 1996b.

[23] J. F. Hoyos. Frutales en Venezuela. Master's thesis, 1994. 2 ed, Monografia $n^{\circ} .36,384 \mathrm{pp}$.

[24] W. J. Wiltbank; N. N. J. Chalfun and O. Andersen. The Jaboticaba in Brazil. Proc. Amer. Soc. Hort. Sci., p. 57-69, 1983. Tropical Region 27 (Part A).

[25] Sítio da Mata. Jabuticaba Híbrida (Myrciaria cauliflora), Jabuticaba Branca (Myrciaria aureana). Sítio da Mata, Sep. 19 2017. https://www.sitiodamata.com.br.

[26] Jaboticaba. Daleys Fruit Tree Nursery, August 2017. 36 Daleys Lane, Kyogle 2474 NSW Australia. https://www.daleysfruit.com.au.

[27] The Cambridge Crystallographic Data Centre (CCDC). Mercury - Crystal Structure Visualisation, exploration and analysis made easy, May 2012. Mercury 3.1 Development (Build RC5). 
[28] A. D. Coelho. Desinfestação de sementes de jabuticabeira "Sabará" na propagação in vitro. TCC Universidade Federal de São João Del Rei: Sete Lagoas, MG, 2017.

[29] Plinia cauliflora (mart.) kausel. Ark. Bot., (3):508, 1956.

[30] Liu Youjie, Fu Jiaxing, Lin Qihua, etc. "Sabala" Gerbera introduced performance and cultivation techniques [J]. South China fruit trees, 40 (4): 97-99, 2011

[31] Zhuang Furei delicious "tropical grape" Garbo [J]. South China fruit trees, 27 (5): 33,1998.

[32] Zhang Shuping, Li Jian. South America Jane fruit Jiabao fruit [J] Fujian fruit tree, (4): 22-24, 2002.

[33] D. R. Dias et al. Vinegar from Jabuticaba Fruit, Food Technol. Biotechnol. 54(3) 351-359, (2016).

[34] J. A. C. Barros; R. M. M. Campos and A. V. B. Moreira. Antioxidant activity in wines made from jabuticaba and grape. J. Brazilian Soc. Food Nutr. 35(1):73-83, 2010. São Paulo, SP.

[35] N. de A. N. Meira, et al. Flavonoids and Anthocyanins in Myrciaria Cauliflora (jaboticaba) Aiming to Cosmetic Applicability. Visão Acadêmica, Curitiba, v. 17, n. 3, Jul. Set./2016 - ISSN 1518-8361.

[36] D. M. L. de Andrade et at. Vasorelaxant and Hypotensive Effects of Jaboticaba Fruit (Myrciaria cauliflora) Extract in Rats. Hindawi Publishing Corporation Evidence-Based Complementary and Alternative Medicine. v. 2015, Article ID 696135, 8 pages. http://dx.doi.org/10.1155/2015/696135.

[37] C. D. de Mendonça. Desenvolvimento Tecnológico de Leite Cultivado Ligth Sabor Jabuticaba (Myrciaria cauliflora) Adicionado de Biomassa e Farinha de Banana (Musa spp.) Verde. Dissertação de Mestrado. Instituto Federal de Educação, Ciência e Tecnologia do Triângulo Mineiro, Campus Uberaba, Uberaba, MG, 2016.

[38] Liang Hai-feng; Liu Shun-Zhi; Jiang Xue-bin and Hu Weirong. Research Progress in Bioactive Substance in Processing of Jaboticaba. College of Life Science, Guangzhou University. Guangdong, Province: 5100006. Chine. 2017.

[39] O. Andersen and V. U. Andersen. As frutas silvestres brasileiras. Globo, São Paulo, 3 ed., 1989. 203 p.

[40] S. Simão. Tratado de fruticultura. Piracicaba, FEALQ, 762 p, 1998.

[41] P. Gomes. Fruticultura brasileira. Nobel, São Paulo, 9 ed., $1983.446 \mathrm{p}$.

[42] TACTRI, COA. Agri-Food Toxicology Laboratory, Council of Agriculture, Executive Yuan. Gaborlus thrips. Nov. 09, 2017. http://www.tactri.gov.tw/wSite/ct?xItem=3691\&ctNode $=333$ $\& \mathrm{mp}=11$.

[43] G1 São Carlos e Araraquara. Safra recorde de jabuticaba gera lucro e emprego em Casa Branca, SP. Globo Comunicações e Participações S. A., Oct. 31 20h11, 2013.

[44] G1 Globo Rural. Pés de jabuticaba carregados geram renda e viram atração em Goiás. G1 Globo Rural, Oct. 092014.

[45] L. Tang; Ting Ting Yuan and Qiu Ping Zhong. Analysis of nutritional components in Myrciaria caulflora. Nonwood Forest Research, 32(2), Jun. 2014.

[46] M. H. C. B. Borges and B. Melo. Cultura da jabuticabeira. Núcleo de Estudos em Fruticultura do Cerrado. Universidade Federal de Uberlândia. Instituto de Ciências Agrárias, 2003.

[47] Redação TV Alteroza. Receitas. Jornal Alteroza on line, Nov. 2001.

[48] Google map. Imagens 2017 CENS. Airbus Digital Globe. Google map. Sep. 22 2017. https://www.google.com.br/maps.

[49] Código Postal. Calculadora da área de um lote. Ciberforma Informática, Sep. 212017.

[50] Uol Universo online. Uol Economia Cotações. Bolsa fecha quase estável após atingir nível recorde na véspera. Uol Universo online, Sep. 192017. 